\title{
The Flower Workshop: A social self-organizing practice in mental health nursing
}

\author{
Maria Alice Ornellas Pereira ${ }^{1}$, Milena Luckesi ${ }^{2}$, Trícia Maria Feitosa Floripes ${ }^{3}$, Alfredo Pereira J r ${ }^{4}$ \\ 1. Graduate Nursing Program, São Paulo State University, Botucatu-SP, Brasil. 2. Centro de Testagem e Aconselhamento \\ em DST/AIDS, Prefeitura do Município de Jundiaí, São Paulo, Brasil. 3. NASF, Secretaria Municipal de Botucatu, São Paulo, \\ Brasil. 4. Graduate Collective Health Program, São Paulo State University, Botucatu-SP, Brasil.
}

Correspondence: Alfredo Pereira Jr. Address: Departamento de Educação - Instituto de Biociências - UNESP - Campus de Rubião Jr. - Botucatu - SP - Brasil, CEP: 18618-970. Email: apj@ibb.unesp.br

Received: February 7, 2014

Accepted: April 17, 2014

Online Published: April 21, 2014

DOI : $10.5430 /$ cns.v2n3p1

URL: http://dx.doi.org/10.5430/cns.v2n3p1

\section{Abstract}

Aims: We depart from the theory of Self-Organizing Systems applied to the practice of mental health nursing in open, public health care services. The present study aimed at understanding how the participants evaluate the importance of the Flower Workshop for their lives.

Methods: It is an investigation of qualitative nature that took place in two units of the Brazilian Family Health Strategy service, using semi-structured interviews and thematic analysis.

Results: The subjects valued the workshop as a facilitating event, promoting the feeling of belonging, enhancement of interpersonal relations and integration of emotional, ideative and corporal experiences in a psychosocial rehabilitation context.

Conclusion: We analysed the reports of participants in three categories, which indicate that the workshop provided: a) An extended care and search for meaning; b) Changes in conduct; and c) An augmented social network.

\section{Key words}

Mental health nursing, Groups, Personal autonomy, Psychosocial rehabilitation, Public health practice

\section{Introduction}

Since 2004 we have been implementing and studying Flower Workshops ${ }^{[1]}$ in the mental health public service in the city of Botucatu, state of São Paulo, Brazil. This practice is based on the theory of self-organizing systems, which has been related to Benedetto Saraceno's Psychosocial Rehabilitation model ${ }^{[2]}$. The Flower Workshop is not a medical therapeutic activity focused on the biological aspects of mental disorder, but a rehabilitation group coordinated by a nurse with assistance of psychology professionals.

The dynamic interaction of experiences along a person's life ${ }^{[3]}$ can be understood with the conceptual tools of the theory of self-organizing systems. Ashby ${ }^{[4]}$ stated that complex organization emerges from the interaction between a system and its environment. Atlan ${ }^{[5]}$ further claims that besides resisting to perturbations, self-organizing systems are also able to "use it to the point of turning it into a factor of organization" (p.38). 
Debrun ${ }^{[6]}$ understands that "There is self-organization each time that a meeting between elements actually (not analytically) distinct develops an interaction without supervisor (or without an omnipotent supervisor) that leads eventually to the establishment of a "form"” (p. 13). The new form originates from the interaction process itself: "The initial conditions (the very existence of the organism, the biological, social and cultural context within which it operates), and exchanges - energy, matter, information, symbols - with the environment play an important role, but only secondary ones” (p. 25-26).

The interactions of experiences that compose the mental life of a person are marked by a search for satisfaction. The dynamic interactions of experiences, leading to satisfaction or frustration, correspond to:

a) A process of self-organization, possibly leading to a state of mental health, or

b) A process of self-disorganization, possibly leading to a crisis that - depending on the vulnerability of the person can induce a mental disorder ${ }^{[3]}$.

In this perspective, a social self-organizing practice would, in principle, help to overcome mental disorder and promote mental health.

\section{The Flower Workshop: Materials and methods}

The creative use of materials by the mental health professional can generate a therapeutic field composed of the individual and the environment. This space is a resting place that provides relief of tension, where the individual can meet other people and have new lived experiences ${ }^{[7]}$. The Flower Workshop is conceived as capable of creating such a field. It consists of social settings where an adequate material is available for making of floral arrangements.

The meetings occur in a monthly basis. We begin with breathing relaxation. The following phases take place:

a) Presentation to the participants of varied choices of objects such as boxes, glasses, cans, disposable plastic that serve as vessels to be decorated, using color paper of varying consistency, as well as tapes, glue, scissors;

b) Living flowers are made available to participants. They are asked to freely choose some of them to make arrangements. These are made using sponges to fix the flowers in vases;

c) Each participant contemplates his own arrangement, as well as the arrangements made by the others;

d) The coordinator asks to the participants how they feel doing the task; if the arrangement elicited emotions, memories and/or ideas.

In each workshop there is a time of making the continent (vessel) and a time of production of the content (flower arrangement). This interplay of continent-content was inspired in Winnicott's art therapy ${ }^{[8]}$. He used this strategy to get in touch with the child in a therapeutic context. It is important to offer opportunities for experiences that allow the subjects to recover their creative ability. In the workshop, it is important that the arrangements are autonomously created by the participants ${ }^{[9]}$.

\section{Methodology}

The study is grounded on the principles of qualitative research, aiming to interpret senses and meanings that a person or group attaches to phenomena of concern ${ }^{[10]}$. 
The Flower Workshop is part of the project entitled "The Construction of Mental Health Care in the Family Health Program", approved by the Ethics Committee for Reasearch with Human Beings of the Faculty of Medicine of Botucatu UNESP, process number 61/2007. The research was conducted in community units of the Family Health Program in the city of Botucatu, São Paulo, Brazil. The program had six years of operation at the time of study. The units are located in areas characterized by low income, low education and poor sanitation.

After the approval of the Ethics Committee, we heard subjects participating in the Workshop in two public heath units of the city of Botucatu. We considered as a criterion of inclusion having six months of participation in the Flower Workshop. All participants from the two units who fulfilled the criterion signed the informed consent and were interviewed. They were nine women and one man, aged between 38 and 79 years, with average time of participation of eight months in the Flower Workshop. The data collected from the 10 subjects was sufficient for saturation.

The clinical history of individuals invited to participate in this study was not taken in consideration, because the workshop is a complementary activity formally unrelated to their medical therapeutic plans. It can contribute to their therapeutic process and to preventive actions, but these desirable effects were not monitored.

In order to evaluate the significance of the workshop for the participants, we accessed their experiences and perspectives, by means of - respectively - techniques of direct observation and semi-structured interviews. Besides information about the subjects, questions included their participation in the workshop, how they evaluate the activity and its contribution for their life.

The interviews were based on the following questions:

- Please describe your experience with the Flower Workshop;

- $\quad$ Please report how the workshop helped (or not) with your problems;

- $\quad$ Please report how this experience is perceived by your family.

The validity and reliability of the results are supported by following the steps of Thematic Analysis ${ }^{[11]}$ throughout the data collection and analysis. A first step was the register of the interviews, using a portable sound recorder. The second step was transcribing the interviews; the third, conducting of several readings; and the fourth, the identification of three themes that express the main ways the subjects understand the Flower Workshop: Expanded Care and Search for Meaning, Behaviour Change and Increased Social Network. The fifth step was discussing the themes and relating them with the literature; the sixth, the selection of parts of the reports to illustrate each theme, and the final step was writing the analysis presented in the next section.

Thematic Analysis can be regarded as a scientific, experimental version of the phenomenological approach of philosophers like Edmund Husserl, Martin Heidegger and Maurice Merleau-Ponty, aiming to understand/comprehend subjective meanings attached to lived experiences by the participants.

According to the guidelines of qualitative research, the completion of this task does not involve statistical methods, but the identification of themes that allow to the scientific interpreter an understanding/comprehension of the subjects' lived experiences. We chose the most relevant parts of the reports that express the identified themes, transcribed and discussed them in the next section.

\section{Results and discussion}

The material obtained from the listening of the subjects proved rich in signification, and allowed an understanding of how they experienced the activity. From our analysis of the reports, three major themes emerged: 


\subsection{Extended care and search for meaning}

The theme of care emerged from the reports as a major factor for improvement of mental health. The participants felt satisfied with the workshop, making possible for them to achieve group recognition. The search for meaning is a vital movement of subjective emancipation of people who live the experience of psychological distress ${ }^{[12]}$. The search for potential latent meanings may contribute to the resumption of paths often interrupted by adversity ${ }^{[13]}$.

Subjects in this study related their participation in the workshop with the idea of extension of care, also seeing themselves as protagonists. One of the participants said: "I like to come here to the workshop, I think I take my time well and it is also better than the meds. I think we have to help”. The report suggests that there is a disposition of the subject to be involved in her own care.

The workshop may contribute to the reordering of perspectives often obscured by internal conflicts and aggravated by the onset of mental disorder. This development is understood as the possibility of stimulating the creative potential of the person to overcome suffering ${ }^{[14]}$. Another participant reports: "I think it would be difficult for me if we did not have the workshop. I think that this activity is good not only for me, it helps many people, this activity cannot stop. I talk with others who participate and they also really like that, each one for a different reason”.

Affective relationships contribute to the quality of care ${ }^{[14]}$; in the constitution of this process, the participants expand the possibilities of expression, contributing to the expansion of latent potentials, providing conditions for emotional development, and making possible for each one to express him/herself in a subjective way ${ }^{[9]}$. A participant reports: "It has been very good. I really like the group. We avoid stress, the body becomes more relaxed, gets quieter, calmer”.

Being creative, the individual (re)discovers the self ${ }^{[15]}$. The proposed practice stimulates a movement of maturity and personal integration. Different ways of experiencing reality were reported by the participants, focusing on their internal disposition: "I plant flowers in my house, I like to mess with the land, but doing the vase here helps me to be more focused...I also like the breathing that we do at the beginning, it makes me feel good... We arrive a little anxious...I think it's good for everyone. I think it could be available to more people, because it's good to relax and receive help in life to take it easy, pay attention to all the little details that are important. From everything I've ever experienced in my life, today I think being more calm helps us to become better to resolve things. So for me this activity helps too much”.

These reports reveal the possibility of interventions that allow people to live better, even with limitations imposed by the impairments of mental disorder.

\subsection{Change in conduct}

The condition of living adaptability and flexibility was mentioned as an achievement in the subjective development process: "I feel fine, I can not wait for the next time to come to the workshop. It has an effect on my personal and family life. My husband says I've improved a lot by attending here. I grew up and learned...that improvements will not happen, it's kinda hard to know, without changing things. I think this activity helps me to see that we can change...we change the color of the paper, make or try to make other arrangements. I think it helps me to open my eyes to see that we can do different vessels". The report suggests that the Flower Workshop can contribute to the realization of necessary changes in everyday life.

The qualities of a human being derive from his/her relations in a situation that occurs during a given time period ${ }^{[16]}$. This temporality of human existence suggests the importance of flexibility and developing positive interpersonal relationships. The development of individual potentials, conceived as a process of self-organization of open systems, depends on environmental conditions ${ }^{[15]}$. 
Data obtained from the interviews allow us to understand part of the temporal dynamics of the participants' mental life, as illustrated by the reports: "I felt a little embarrassed when I came here the first time, it looked like I would not do it, it seemed that it would not work, my hand could not cut the paper, everything was difficult, scissors weighed...but I was getting better. Now I think I 'm not so embarrassed, I think that this activity was good for me, helped me see that I do it my way, I make my beautiful vase and then take it home to decorate and show what I did, and this is nice...It is very good...When would I imagine that I was able to make a vase? My husband applauds every time I come with a vase at home. I moved, I went through cancer, I was always alone, now I have company. It is a mental hygiene, I do everything to come here”.

Winnicott ${ }^{[17]}$ emphasizes the power of the creative act to change life and improve the health of every individual, without disregarding the biological and social life conditions. Building on the creative act, Art Therapy is the use of material mediators in the process of searching for the self, providing conditions for an emotional development ${ }^{[7]}$.

The possibility offered to the persons to express themselves, using flowers as materials, may contribute to the condition of feeling alive and creative, as expressed in the reports: "When I come in workshop I calm myself, I seem to be concentrated; it seems that I pay attention to myself. I can watch what I can do here, enjoy what I do and it has been good! I learned a lot, knowing that I am able to do something. For me it brought change, I could find that I am able”.

The reports suggest an appropriation by the subject of his existential condition: "Before the Workshop I warmed up with anything! Now it seems that even living with my brothers in my house I got better...Sometimes someone spoke something, I already burst, it was my mood. Not now, I just do not argue, I 'm better. I'm not so nervous, it did much for me, I feel it has helped me to think".

These experiences facilitate the subjective process of psychosocial rehabilitation, supporting strategies aimed at increasing opportunities for exchanges of resources and affections, in order to create an enabling effect on people requiring support ${ }^{[18]}$. Developing feelings and experiences may promote social integration and harmony.

\subsection{Augmented social network}

In the process of overcoming mental disorder and psychological suffering, the level of self-organization and self-esteem that is achieved facilitates social inclusion. When the person himself believes that she is unable or impotent against the dynamics of her life, there is a state of inertia that decreases the condition to cope with life's difficulties.

This situation can be modified with the support of a social network, as reported by the participants: "I always enjoyed the workshop, I get distracted, I forget the problems when I do the vase. I like flowers, but had never done anything like this"; "I think if you're having fun, you are improving yourself. Even if it is not well done, the important thing is to be doing, be participating...I feel good here, if I did not feel I would not come, and I 'm always here, it's been a year”.

The speeches suggest that the participants have benefited from the establishment of interpersonal relations. The attitudes of collaboration in the group have generated a feeling of solidarity, belonging and improved self-esteem. Thus, we consider that the moments of group interactions facilitate the expansion of social identities and contribute to the expansion of social networks: "For me the workshop brought a departure from isolation. I was always very shy. I attend to the workshop here in freedom, I talk to each one, we talk to each other. We get better with more interactions, because I ' $m$ not so much a talking person. The workshop makes me more communicative, I can talk to people that are there, I can make my vessel, it has helped me to open up more, to see what I can get and see what I did. I think it has helped me”. This kind of process has been theorized in the psychology of personality. The self develops in cycles ${ }^{[17]}$. This thinking leads to a reflection about the value of favouring conditions for emotional development, allowing each one to express him/herself a genuine way. 


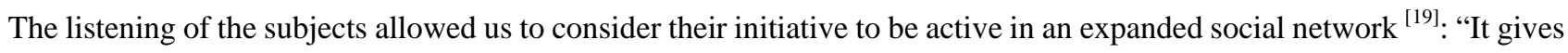
a sense of relief, it is good to be in a group...For me it is a therapy, I forget my problems of nerves. I am more lively, I have more willingness to work, planting flowers, more desire for good changes”. The reports suggest the enhancement of living made possible by an interaction between the practice performed in the health service and the subject's personal life: "It was the first place that most helped me psychologically, because I was an isolated person. Without the group, I wanted to kill myself. Here I learned to appreciate nature, I learned to make a garden, to see the beauty of the flowers that I had not seen before, I learned to live with the group”. In spite of the mention of death, it is possible to conjecture that the situation offered by interactive activity may have amplified the social network in a dynamic and stimulating joint collaboration for the emergence of life potentials. This report reiterates the importance of providing conditions of emotional expression conditions to the subjects, allowing the "the emergence of a spontaneous gesture, a recovery...of creative ability that makes the individual feel alive and real" ${ }^{[9]}$.

\section{Conclusion}

The reports produced by the subjects of this study indicate that the Flower Workshop is a facilitating event, promoting the feeling of belonging, and promoting greater integration of emotional, ideational and bodily experiences of the participants, thus reducing anxiety and distress factors. Beyond the making of the flower arrangement, the human encounter facilitates the elaboration of feelings and experiences by the participants, and encourages each one to integrate their experiences in more harmonic ways, leading to significant processes of change in their lives.

We analysed the reports of participants in three categories, which indicate that the workshop provided: a) An extended care and search for meaning; b) Changes in conduct; and c) An augmented social network. These results highlight the importance of giving support to the person, promoting his/her condition of mental health. Effective care involves not only the medical intervention on the process of mental disorder, but should also allow the search for meaningful social experiences, composing the psychosocial rehabilitation process that is complementary to medical care.

The contemporary expansion of mental health assistance has brought theoretical and practical challenges concerning the plurality and complexity of the area. This ongoing process calls for interventions in multiple aspects of the assistance. Currently, conventional medical care is necessary, but limited in regard to the existential, subjective aspects of psycho-social rehabilitation. This research can contribute to better patient outcomes, by means of putative psychosomatic effects of these satisfying new social experiences on the brain and body of the participants.

Our results also contribute to the literature on psychosocial rehabilitation nursing, offering a new resource for professional practice in a public health system. The Flower Workshop can effectively promote an expression of potentialities, stimulate human development and contribute for the participants being protagonists in their life process. On the basis of these results, we recommend the Flower Workshop as a complementary, low cost and general purpose group, to promote psycho-social rehabilitation.

\section{Acknowledgment}

FAPESP (MAOP and APJ) Grant 2010/52627-9 Thematic Project “Systemics, Self-organization and Information”.

\section{References}

[1] Pereira Jr A, Pereira MAO. The Flower Workshop in Psychosocial Rehabilitation: A Pilot Study. Issues in Mental Health Nursing. 2009: 30: 47-50. PMid:19148821 http://dx.doi.org/10.1080/01612840802555216

[2] Lussi IAO, Pereira MAO, Pereira Jr A. A Proposta de Reabilitação Psicossocial de Saraceno: um Modelo de Auto-Organização? Revista Latino-Americana de Enfermagem. 2006; 14: 448-456. PMid:16927004 http://dx.doi.org/10.1590/S0104-11692006000300021 
[3] Lussi IAO Pereira Jr A Freitas HI. Proposta de um Instrumento de Auto-Avaliação em Saúde Mental. Cadernos de Terapia Ocupacional da UFSCar. 2006; 12: 5-14.

[4] Ashby WR. Principles of the Self-Organizing System. In: Von Foerster H and Zopf GW (Org) Principles of Self-Organization. Oxford: Pergamon; 1962.

[5] Atlan H. Entre le Cristal et la Fumée, Seuil, Paris. 1979.

[6] Debrun, M. A Idéia de Auto-Organização. In: Debrun M Gonzales MEQ Pessoa Jr O. (Org.) Auto-Organização: Estudos Interdisciplinares em Filosofia, Ciências Naturais, Humanas e Artes. Campinas: UNICAMP, Centro de Lógica, Epistemologia e História da Ciência: 1996.

[7] Aiello-Vaisberg TMJ. Sofrimento Humano e Práticas Clínicas Diferenciadas. In: Aiello-Vaisberg TMJ, Ambrósio FF (Org.) Trajetos do Sofrimento: Desenraizamento e Exclusão. I Seminário Temático Ser e Fazer. São Paulo: USP/Instituto de Psicologia; 2002.

[8] Winnicott D. O Brincar e a Realidade. Rio de Janeiro: Imago; 1975.

[9] Aiello-Vaisberg TMJ. A Materialidade na Oficina Psicoterapêutica Arte de Papel. In: Aiello-Vaisberg TMJ Ambrósio FF (Org.) Trajetos do Sofrimento: Desenraizamento e Exclusão. I Seminário Temático Ser e Fazer. São Paulo: USP/Instituto de Psicologia; 2002.

[10] Turato ER. Tratado da Metodologia da Pesquisa Clínico-Qualitativa 3th.ed. Petrópolis: Vozes; 2008.

[11] Bardin, L. L'analyse de Contenu. Paris: Presses Universitaires de France; 1993.

[12] Rotelli F, Leonardis O, Mauri D. Desinstitucionalização, uma outra via: a reforma psiquiátrica italiana no contexto da Europa ocidental e dos países avançados. In: Nicácio F. (Org.) Desinstitucionalização. São Paulo: Hucitec; 1990. PMid:2290555

[13] Merhy EE. Reforma Psiquiátrica no Cotidiano: multiplicidades no cuidado e por uma ética cidadã. Manejos das Ações Relacionais. In: Merhy EE, Amaral H. A Reforma Psiquiátrica no Cotidiano II. São Paulo: Hucitec; 2007.

[14] Souza AMB, Moraes MC, May VA. A Gestão do Cuidado para a Vida Nueva. Cad Bras Saude Mental. 2009 ; 1(1): 1-10.

[15] Winnicott D. The Maturational Processes and the Facilitating Environment: Studies in the Theory of Emotional Development. International Psycho-Analytical Library, 64: 1-276. London: The Hogarth Press and the Institute of Psycho-Analysis, 1965.

[16] Bleger J. Psicologia da Conduta. Porto Alegre: Artes Médicas; 1989.

[17] Neto JFS. A Saúde entre Norma Social e Vivido Subjetivo: Winnicott e Gadamer. In: Bezerra Jr, Ortega F. Winnicott e seus interlocutores. Rio de Janeiro (RJ): Relume Dumará; 2007.

[18] Safra G. Experiência Estética na Constituição da Transicionalidade. In: Catafesta IFM. D.W. Winnicott na Universidade de São Paulo. São Paulo: Instituto de Psicologia Clínica da Universidade de São Paulo; 1996.

[19] Saraceno B. La fine dell'intrattenimento. Manuale di riabilitazione psichiatrica. Milano: ETAS Libri Edizioni; 1995.

[20] Sluzki CE. A Rede Social na Prática Sistêmica: Alternativas Terapêuticas. 3th. ed. São Paulo: Casa do Psicólogo; 1997. 